\title{
Seasonal and spatial species richness variation of dung beetle (Coleoptera, Scarabaeidae s. str.) in the Atlantic Forest of southeastern Brazil
}

\author{
Malva I. Medina Hernández ${ }^{1} \&$ Fernando Z. Vaz-de-Mello²
}

${ }^{1}$ Instituto de Biociências, Campus de Rio Claro, Universidade Estadual Paulista, Rio Claro-SP, Brasil. Current address: Depto. Ecologia e Zoologia, Centro de Ciências Biológicas, Universidade Federal de Santa Catarina, 88010-970 Florianópolis-SC, Brasil. malvamh@yahoo.com

${ }^{2}$ Departamento de Biodiversidad y Ecología Animal, Instituto de Ecología, A. C. Veracruz, México. Current address: Departamento de Biologia e Zoologia, Instituto de Biociências, Universidade Federal de Mato Grosso, 78060-900 Cuiabá-MT, Brasil. vazdemello@gmail.com

\begin{abstract}
Seasonal and spatial species richness variation of dung beetles (Coleoptera, Scarabaeidae s. str.) in the Atlantic Forest of southeastern Brazil. The knowledge on Atlantic Forest scarab beetle fauna is quite limited. This biome is strongly degraded and these insects can be used as bioindicators since they are sensitive to forest destruction and show distinct organizational patterns in forest fragments or in areas that have been deteriorated by human activity. Thus, a study of the Scarabaeidae (sensu stricto) dung beetles fauna that inhabit Serra do Japi, São Paulo, Brazil $\left(23^{\circ} 12^{\prime}-23^{\circ} 22^{\prime}\right.$ $\mathrm{S}$ and $46^{\circ} 53^{\prime}-47^{\circ} 03^{\prime} \mathrm{W}$ ) was carried out; the monthly species richness was analyzed in six areas during one year and the vegetation's structural physiognomy was described. The areas included a conserved and a degraded valley, a northward and a southward hillside, a hilltop, and an area of secondary forest growing under eucalyptus trees. The specimens were collected using four pitfall traps baited with human feces, which remained at each spot during 48 hours. Between September, 1997 and August, 1998, 3524 individuals of 39 species were collected; the most abundant were: Canthidium trinodosum, Eurysternus cyanescens, Uroxys kratochvili, Scybalocanthon nigriceps, Uroxys lata, Canthonella sp., Dichotomius assifer, Deltochilum furcatum, Canthidium sp.2, Canthon latipes, Deltochilum rubripenne, Eurysternus sp., and Dichotomius sp.1. The number of individuals and species was greater in the hot, rainy season, when there was a correlation between the number of species and the mean annual temperature $\left[r^{2}=0.69 ; p<0.01\right]$. The lower winter richness was most pronounced in the conserved valley, while richness remained relatively constant in the degraded valley; abundance was much higher in the degraded valley. The cluster analysis showed that the valleys and hillsides are the most similar in relation to species composition and abundance, yet different from the secondary forest with eucalypts and the hilltop.
\end{abstract}

KEYWORDS. Dung Beetles; diversity; ecology; richness; Scarabaeidae.

\begin{abstract}
RESUMO. Variação sazonal e espacial da riqueza de espécies de besouros coprófagos (Coleoptera, Scarabaeidae s. str.) em Mata Atlântica do sudeste do Brasil. O conhecimento da fauna de besouros escarabeídeos da Mata Atlântica é bastante reduzido. Este bioma encontra-se fortemente degradado sendo que estes insetos podem ser usados como bioindicadores já que são sensíveis à destruição de florestas, apresentando distintos padrões de organização em fragmentos ou em áreas deterioradas pela ação humana. Foi realizado um levantamento dos Scarabaeidae (sensu stricto) coprófagos que habitam a Serra do Japi, São Paulo, Brasil $\left(23^{\circ} 12^{\prime}-23^{\circ} 22^{\prime}\right.$ S e $\left.46^{\circ} 53^{\prime}-47^{\circ} 03^{\prime} \mathrm{W}\right)$ analisando a riqueza mensal de espécies ao longo de um ano em seis áreas, nas quais foram realizadas descrições fisionômicas estruturais da vegetação. As áreas incluíram um vale conservado e um degradado, uma encosta sul e uma norte, um topo de morro e uma área de mata secundária sob eucaliptos. Através de quatro armadilhas de queda iscadas com fezes humanas, que permaneceram 48 horas em cada área, entre IX/1997 e VIII/1998 foram coletados 3524 indivíduos de 39 espécies, sendo as espécies mais abundantes: Canthidium trinodosum, Eurysternus cyanescens, Uroxys kratochvili, Scybalocanthon nigriceps, Uroxys lata, Canthonella sp., Dichotomius assifer, Deltochilum furcatum, Canthidium sp.2, Canthon latipes, Deltochilum rubripenne, Eurysternus sp. e Dichotomius sp.1. O número de indivíduos e de espécies foram maiores na época quente e chuvosa, havendo correlação entre o número de espécies e a temperatura média mensal $\left[\mathrm{r}^{2}=0,69 ; \mathrm{p}<0,01\right]$. A menor riqueza no inverno foi mais acentuada no vale conservado enquanto no vale degradado a riqueza manteve-se relativamente constante; a abundância foi extremamente maior na área de vale degradado. A análise de agrupamento mostrou que os vales e as encostas são mais semelhantes quanto a composição e abundância de espécies, diferindo tanto da mata secundária com eucaliptos como do topo do morro.
\end{abstract}

PALAVRAS-CHAVE. Besouros; diversidade; ecologia; riqueza; Scarabaeidae.

The family Scarabaeidae (sensu stricto) includes approximately 6000 known species, many of which are found abundantly in terrestrial humid tropical environments. Most species biology and ecology is poorly known (Hanski 1991) and for many groups there is little taxonomical information available, especially in the case of genera comprising small species, such as Ateuchus Weber, 1801, Canthidium Erichson, 1847, and Uroxys Westwood, 1842 (Gill 1991). The South
American Scarabaeidae fauna, distributed over the large areas of tropical forest with long evolutionary histories, is high in species richness. Presently, there are 618 species recorded for Brazil, but it is likely that this number will surpass 1200 species since there are data lacking from several regions (Vaz-de-Mello 2000).

Scarabaeidae $s$. str. is characterized by the fact that most species use decomposing organic material as larval and adult 
food. Species can be saprophagous (feeding on decomposing plant material), coprophagous (feeding on feces), necrophagous (feeding on carcasses), or generalists (feeding on all of the foods mentioned) (Halffter \& Matthews 1966; Halftter \& Edmonds 1982; Cambefort 1991). The evolution of the family's feeding behavior (which was probably saprophagous in the beginning) must have caused the ecological scattering of those species that later became specialized in coprophagy, due to the large number with this kind of diet (Halffter \& Matthews 1966; Cambefort 1991).

The availability of vertebrate feces, especially mammals, as a food resource for the Scarabaeidae s. str. varies a lot in space and time, and might be important for the stabilization or fluctuations of the population size. The resource levels available is likely diminished drastically after the rapid disappearance of large mammals and birds in degraded forests; accordingly, food has become a limiting factor in species' population dynamics and has directly affected community structures. Dung beetle communities are very sensitive to forest destruction and show distinct organization patterns when studied in tropical forest fragments or in areas that have been deteriorated by human activity (Howden \& Nealis 1975; Peck \& Forsyth 1982; Klein 1989; Janzen 1983; Halffter et al. 1992; Davis 1994; Didham et al. 1998; Lobo \& Martín-Piera 1999; Davis et al. 2001; Halffter \& Arellano 2002; Hernández 2003). Therefore, by analyzing their communities, they can be used as indicators of environmental change. These organisms - considered to be bioindicators - are useful for studying the effects of deforestation and for evaluating the changes that ecosystems as a whole can suffer as a result of environmental alterations (Halffter et al. 1992; Halffter \& Favila 1993; Davis et al. 2001; McGeoch et al. 2002; Gardner et al. 2008).

The Atlantic Forest, with its high species richness and high levels of endemism (Brown \& Brown 1992), is among the most endangered of tropical forests, and was intensely degraded especially due to wood extraction and to human population growth; it is estimated that only $7.6 \%$ of the original vegetation cover remains (Ministério do Meio Ambiente 1999). There are few studies of the dung beetle fauna on this biome (see Louzada \& Lopes 1997; Vaz-de-Mello \& Louzada 1997; Vaz-de-Mello 2000; Hernández 2002, 2003; Endres et al. 2005, 2007); thus, this study aimed to survey the dung beetles that inhabit Serra do Japi's Atlantic Forest and to analyze the spatial and seasonal variation of species richness in areas with different vegetation structure during one year.

\section{MATERIALAND METHODS}

The species were surveyed at Serra do Japi, located between $23^{\circ} 12^{\prime}$ and $23^{\circ} 22^{\prime} \mathrm{S}$ and between $46^{\circ} 53^{\prime}$ and $47^{\circ} 03^{\prime} \mathrm{W}$. The area $\left(354 \mathrm{~km}^{2}\right)$ is located in the western portion of São Paulo State's Atlantic plateau, Brazil; altitude varies between 700 and $1300 \mathrm{~m}$. Mean annual temperature varies between $15.7^{\circ} \mathrm{C}$ (in the higher areas) and $19.2^{\circ} \mathrm{C}$ (in the lower areas), while annual precipitation varies from $1907 \mathrm{~mm}$ to $1367 \mathrm{~mm}$, with predominant rainfall in the months of December and

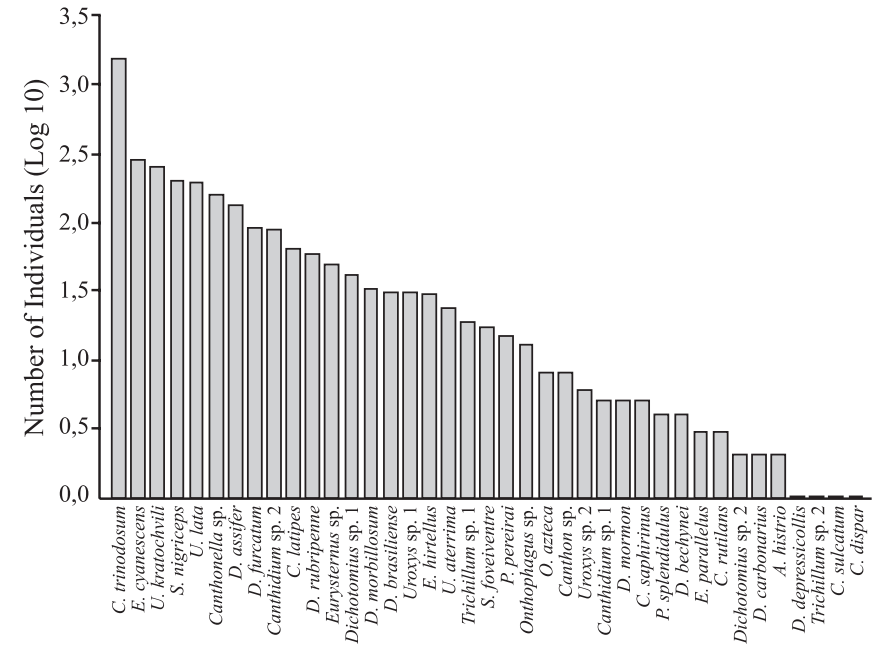

Fig. 1. Diagram of the abundance distribution of the 39 species of Scarabaeidae s. str. collected with human baited pitfall traps at Serra do Japi, São Paulo, Brazil, during one year of research.

January (Pinto 1992). Mesophilous semideciduous forests (seasonal forests with a period of leaf loss during the year's driest and coolest times) occupy most of the mountain. Tree diversity is high and maximum tree height varies between 20 and $25 \mathrm{~m}$ (Leitão-Filho 1992).

Dung beetle collections were undertaken with pitfall traps constructed using plastic containers $17 \mathrm{~cm}$ wide and $12 \mathrm{~cm}$ deep filled with neutral detergent at a concentration of $2 \%$. A disposable plate was placed over the traps as a protection against rain and a central structure (a $25 \mathrm{ml}$ plastic cup) with 10 $\mathrm{g}$ human feces was used as bait to attract the insects.

Monthly collections were carried out at six areas between September 1997 and August 1998; in each area four traps were placed along a transect at intervals of $50 \mathrm{~m}$, at least $10 \mathrm{~m}$ from the dirt roads that cross the forest. The 24 traps remained in the field for 48 consecutive hours each month. The collection areas had different types of vegetation, which comprise Serra do Japi's characteristic "mosaic": area 1 is a valley $(1050 \mathrm{~m})$ $(\mathrm{V})$; area 2 is also a valley $(1000 \mathrm{~m})$, but is visibly more degraded than the first (DV); area 3 is a hillside that faces south $(1100 \mathrm{~m})$ and is influenced by the sea's humidity (SS); area 4 is a hillside that faces north, and is drier (1025 m) (NS); area 5 is at the top of a hill $(1150 \mathrm{~m})(\mathrm{H})$; and secondary forest grows over area 6 , under a 30-year old eucalyptus plantation (1100 m) (SE).

Each area was described in relation to its vegetation's physiognomic structure in order to allow a comparison between the areas sampled. The trees' most important parameters were measured inside an area of $50 \times 2 \mathrm{~m}$. Parcels were delimited in each area and the following measurements were taken for each tree with diameters (DBH) e" $10 \mathrm{~cm}: 1)$ Location inside the parcel; 2) Perimeter; 3) Height; 4) Treetop diameter.

In the lab, insects were mounted with entomological pins, placed in a drying oven $\left(45^{\circ} \mathrm{C}\right)$ for 48 hours, then labeled. Voucher specimens were deposited at the Museu de Zoologia da Universidade de São Paulo (University of São Paulo's 

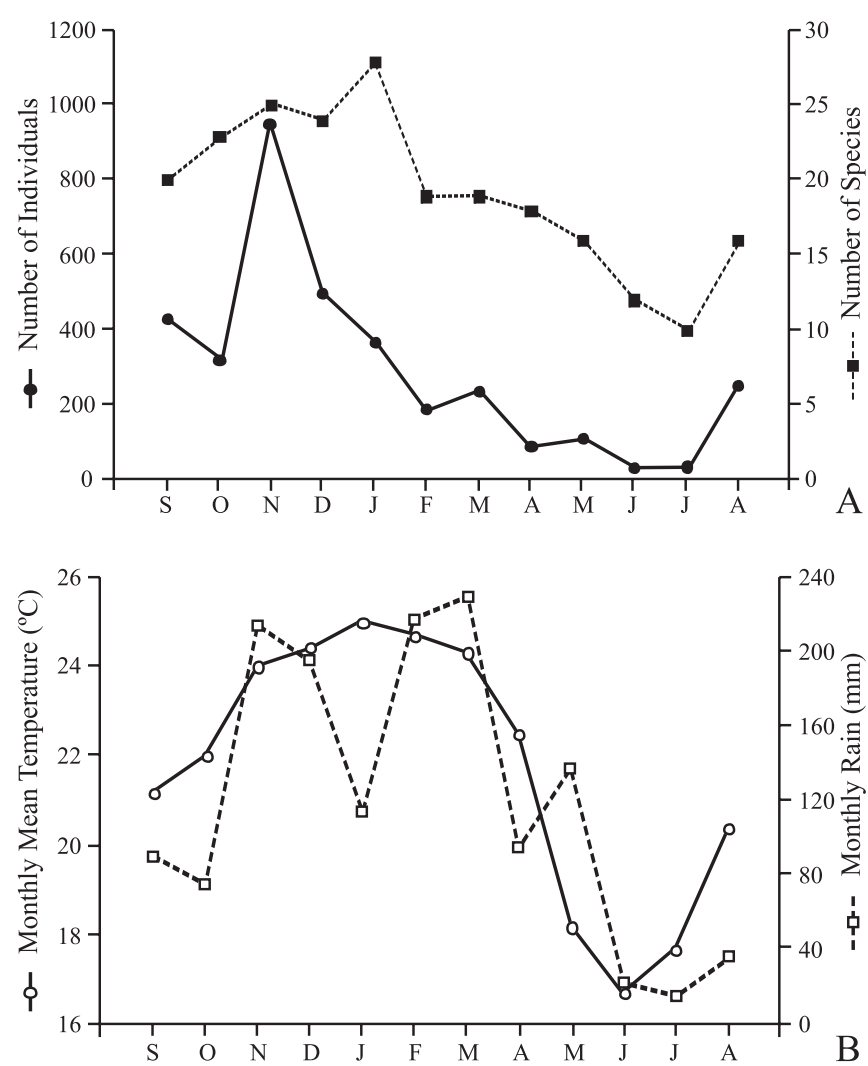

Fig. 2. (a) Abundance and richness of dung beetles collected per month at Serra do Japi, São Paulo, Brazil, from September 1997 to August 1998; (b) Climatic data (mean temperature and monthly rainfall) of the area during the year studied.

Zoology Museum) and at the Coleção Entomológica Adolf Hempel do Instituto Biológico de São Paulo (São Paulo Biological Institute's Adolf Hempel Entomological Collection).

Data organization and statistical analyses were carried out using the Statistica for Windows v.4 software (Statsoft 1998); this included correlation, regression, and cluster analyses the latter using the Unweighted Pair Group Method with Arithmetic Mean (UPGMA). The software Ecological Methodology v.5.2 (Kenney \& Krebs 2000) was used to calculate similarities between collection areas by applying Morisita's Index, which includes each species' relative abundance data (square root) for each collection area. The same program was used to estimate the species richness based on the Jackknife method. A 95\% confidence interval was included when estimating each area's richness during the different seasons in order to check for significant differences. A canonical correspondence analysis was carried out comparing each species' relative abundance (square root) in each collection area and the structural complexity measurements of each area's trees (with the exception of the eucalypts' data, which height would invalidate the analysis); the Canoco for Windows v. 4.5 software was used for this analysis (Ter Braak \& Smilauer 1997-2002).

Mean temperature and total rainfall for each month of the collection period were obtained from the Instituto Agronômico de Campinas (Campinas Agronomical Institute) to evaluate their relationship with the community's patterns through correlation and regression analyses.

\section{RESULTS}

A total of 3524 individuals were collected during the yearlong study and were identified into 39 species in 16 genera from six tribes; 27 species were fully identified, while 12 were assigned only to genera (Table I).

The relative abundance of individuals shows that the dominant species was Canthidium trinodosum (Boheman, 1858), which represented $45.8 \%$ of all individuals. Other relatively abundant species were: Eurysternus cyanescens Balthasar, 1939 (8.3\%), Uroxys kratochvili Balthasar, 1940 (7.2\%), Scybalocanthon nigriceps (Harold, 1868) (5.8\%), Uroxys lata Arrow, 1933 (5.6\%), Canthonella sp. (4.6\%), and Dichotomius assifer (Eschscholtz, 1822) (3.8\%). Less abundant species were: Deltochilum furcatum (Castelnau, 1840) and Canthidium sp.2 (both with 2.6\%), Canthon latipes Blanchard, 1845 (1.8\%), Deltochilum rubripenne (Gory, 1831) (1.7\%), Eurysternus sp. (1.4\%), and Dichotomius sp.1 (1.2\%). The remaining species represented less that $1 \%$ (Figure 1).

The greatest number of individuals was collected in November (945 individuals $-26.8 \%$ of the total), while $92.2 \%$ of the insects $(\mathrm{n}=3249)$ were found between September and March plus August, the last month sampled. Conversely, the number of species collected monthly varied between $70 \%$ of the total species in January $(\mathrm{n}=28)$ and $25 \%$ in July, when only 10 species occurred (Figure 2a). Both the number of individuals and the number of species collected per month is related to climatic conditions - more individuals and species occur during the hot, humid season (Figure 2b). There was a positive and linear relationship between the number of species (S) and the mean monthly temperature $(T)\left[r^{2}=0.69 ; p<0.01\right]$; the regression equation $S=-13.36+1.49 \mathrm{~T}$ can be used to infer an increase in three species for every $2^{\circ} \mathrm{C}$ augment in temperature. However,

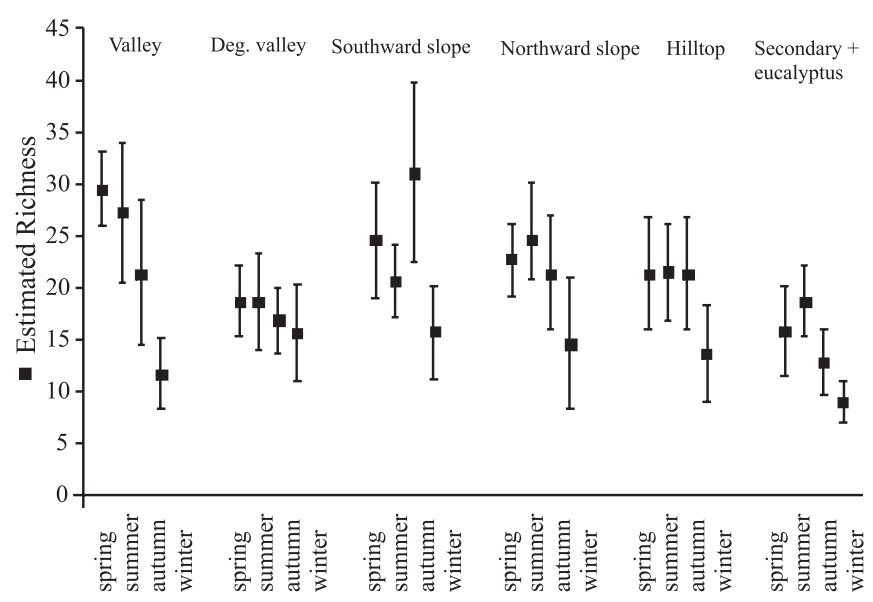

Fig. 3. Estimated dung beetle species richness using the Jackknife method (95\% confidence interval) of the species collected from six areas of Serra do Japi, São Paulo State, Brazil, throughout one year. 


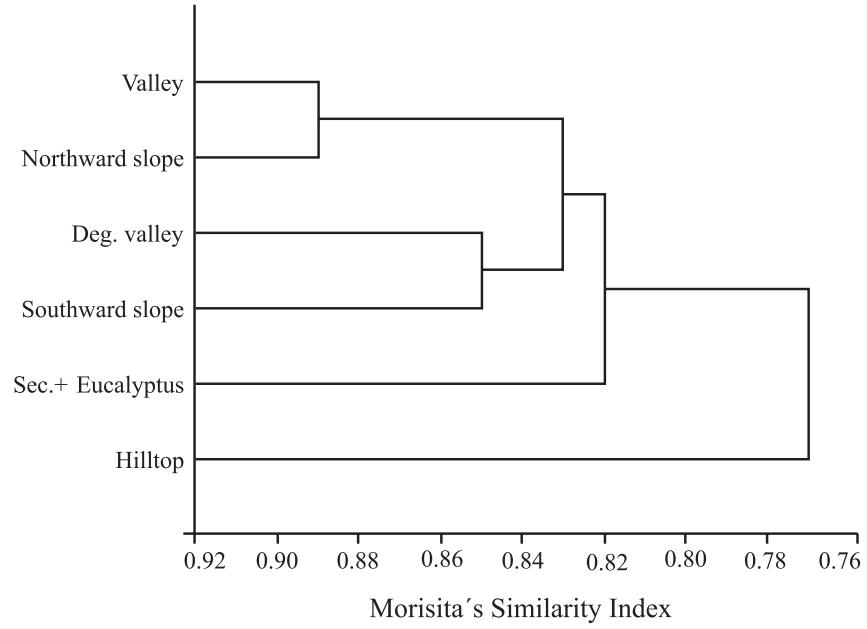

Fig. 4. Cluster analysis based on Morisita's index of similarity showing the different areas of dung beetle collection in Serra do Japi, São Paulo State, Brazil.

there is also a positive and linear correlation between the two climatic variables, precipitation and temperature $[\mathrm{r}=0.76$; $\mathrm{p}<0.01]$, so either temperature or rain could be affecting species' abundance and richness.

Six species were present throughout the year (although their relative frequency varied from month to month): Canthidium trinodosum and Canthonella sp. were collected uninterruptedly throughout the year, while Uroxys lata, Deltochilum brasiliense (Castelnau, 1840), Dichotomius assifer, and Eurysternus cyanescens were absent only from one of the collection months. Another nine species that were present in most collections and that also had no well defined temporal variation pattern were Uroxys aterrima Harold, 1867, U. kratochvili, Uroxys sp.1, Eurysternus hirtellus Dalman, 1824, Eurysternus sp., Trichillum sp. 1, Canthidium sp. 2, and Paracanthon pereirai d'Andretta \& Martínez, 1957.

The species that showed seasonality patterns (concentrated during spring and summer) were: Deltochilum furcatum, D. morbillosum Burmeister, 1848, and D. rubripenne, as well as Canthon latipes, Scybalocanthon nigriceps, Sylvicanthon foveiventre (Schmidt, 1920), and Dichotomius sp.1. The remaining 17 species were not very abundant (less than seven individuals per collection) and it was not possible to make inferences on their temporal activity pattern over the year. It is also important to note that a single species showed an autumn-winter seasonal pattern: Dichotomius bechynei Martínez, 1973.

Each collection area's species richness - evaluated using the jackknife method - showed that richness undergoes strong seasonal changes during the year, with smaller values during the winter months (Figure 3). This seasonal pattern is not the same in all of Serra do Japi's areas, but is more pronounced in the conserved valley, where 29.5 species were estimated to the spring and 11.7 to the winter. Conversely, richness was relatively constant throughout the year in the degraded valley (18.7 species in spring and 15.6 species in winter). Although no significant, when comparing the two areas we can see that the lowest estimated richness values were found in the degraded valley and in the secondary forest with eucalypts (in fact, the latter had only 8.9 species estimated for winter) (Figure 3).

There was great variation in abundance for the dung beetles collected in each of Serra do Japi's sampled areas. The location with the most individuals was the degraded valley (1380 individuals or $39.2 \%$ of the total number collected). This amount of individuals was mostly due to the abundance of a single species, Canthidium trinodosum, of which 1031 individuals were collected (Table I). Next came the hillsides: the southward hillside had 672 individuals, while the northward hillside had 514. The other areas were similar to one another: 368 individuals were collected in the conserved valley, 305 in the secondary forest with eucalypts, and 285 in the hilltop (Table I).

There were no great numerical variations between each area's total species richness; 29 species were collected from the conserved valley and 23 from the degraded valley. The greatest richness was found in the southward hillside (30 species), while 24 species were collected from the northward hillside. A total of 25 species were obtained from the hilltop and only 22 species from the secondary forest with eucalypts (Table I).

In general, the most abundant species ( $>50$ individuals collected) were distributed throughout all of the areas, although their relative abundance varied and showed habitat preferences. Nevertheless, Scybalocanthon nigriceps is different from the rest in relation to its distribution - it did not occur in the degraded valley, although its frequency was high in all of the other collection areas (Table I).

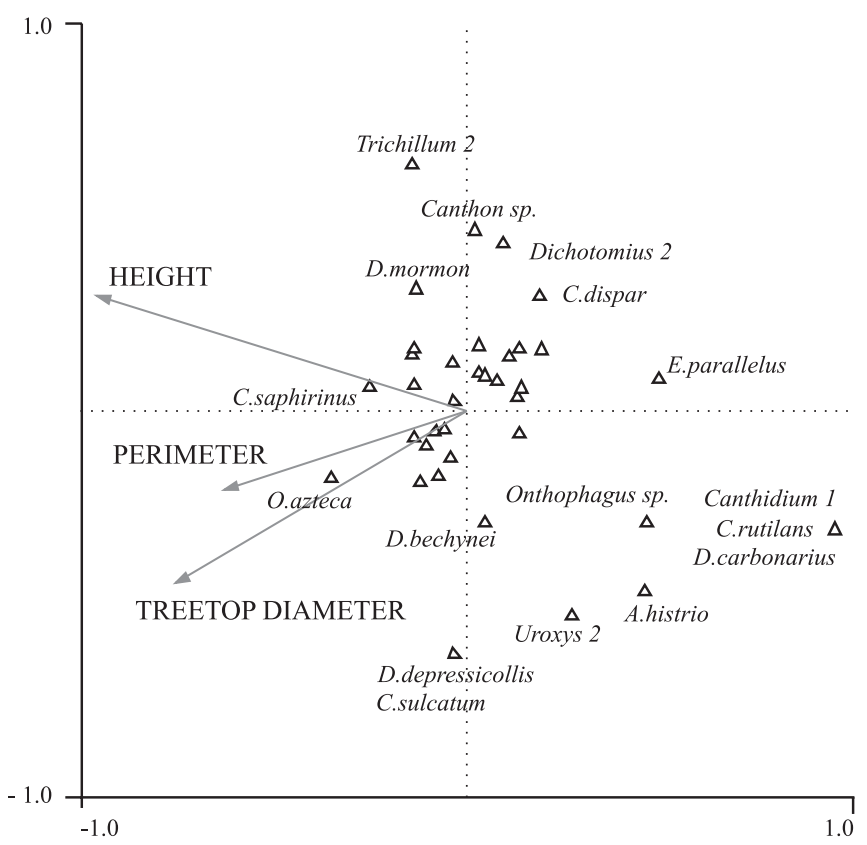

Fig. 5. Correspondence analysis between tree measurements from the six collection areas and abundance of Scarabaeidae s. str. species collected at Serra do Japi, São Paulo State, Brazil. 
Table I. Dung beetle species of Scarabaeidae s. str. collected at Serra do Japi, São Paulo State, Brazil, in monthly collections carried out along one year in six sample areas: V=valley; DV=degraded valley; SS=southward slope; NS=northward slope; H=hilltop; SE=secondary forest and eucalyptus.

\begin{tabular}{|c|c|c|c|c|c|c|c|c|}
\hline TRIBE & SPECIES & $\mathrm{V}$ & DV & SS & NS & $\mathrm{H}$ & $\mathrm{SE}$ & Total \\
\hline \multirow[t]{13}{*}{ Ateuchini } & Ateuchus near histrio (Balthasar, 1939) & 0 & 0 & 1 & 0 & 1 & 0 & 2 \\
\hline & Canthidium dispar Harold, 1867 & 0 & 0 & 0 & 1 & 0 & 0 & 1 \\
\hline & Canthidium near sulcatum (Perty, 1830) & 0 & 0 & 1 & 0 & 0 & 0 & 1 \\
\hline & Canthidium trinodosum (Boheman, 1858) & 43 & 1031 & 174 & 164 & 128 & 74 & 1614 \\
\hline & Canthidium sp. 1 & 0 & 0 & 0 & 0 & 5 & 0 & 5 \\
\hline & Canthidium sp. 2 & 6 & 46 & 17 & 18 & 2 & 1 & 90 \\
\hline & Trichillum sp. 1 & 1 & 8 & 4 & 4 & 2 & 0 & 19 \\
\hline & Trichillum sp. 2 & 1 & 0 & 0 & 0 & 0 & 0 & 1 \\
\hline & Uroxys aterrima Harold, 1867 & 7 & 4 & 1 & 9 & 3 & 0 & 24 \\
\hline & Uroxys kratochvili Balthasar, 1940 & 8 & 62 & 158 & 7 & 2 & 18 & 255 \\
\hline & Uroxys lata Arrow, 1933 & 64 & 38 & 75 & 5 & 11 & 3 & 196 \\
\hline & Uroxys sp. 1 & 15 & 5 & 4 & 6 & 0 & 1 & 31 \\
\hline & Uroxys sp. 2 & 0 & 0 & 5 & 0 & 1 & 0 & 6 \\
\hline \multirow[t]{8}{*}{ Coprini } & Dichotomius assifer (Eschscholtz, 1822) & 16 & 31 & 57 & 18 & 2 & 9 & 133 \\
\hline & Dichotomius bechynei Martínez, 1973 & 0 & 0 & 3 & 1 & 0 & 0 & 4 \\
\hline & Dichotomius carbonarius (Mannerheim, 1929) & 0 & 0 & 0 & 0 & 2 & 0 & 2 \\
\hline & Dichotomius depressicollis (Harold, 1867) & 0 & 0 & 1 & 0 & 0 & 0 & 1 \\
\hline & Dichotomius mormon (Ljungh, 1799) & 2 & 1 & 0 & 1 & 0 & 1 & 5 \\
\hline & Dichotomius sp. 1 & 10 & 2 & 6 & 23 & 1 & 0 & 42 \\
\hline & Dichotomius sp. 2 & 0 & 0 & 0 & 0 & 0 & 2 & 2 \\
\hline & Ontherus azteca Harold, 1869 & 0 & 6 & 1 & 0 & 0 & 1 & 8 \\
\hline \multirow[t]{4}{*}{ Eurysternini } & Eurysternus cyanescens Balthasar, 1939 & 65 & 79 & 59 & 26 & 21 & 41 & 291 \\
\hline & Eurysternus hirtellus Dalman, 1824 & 0 & 1 & 10 & 3 & 3 & 13 & 30 \\
\hline & Eurysternus parallelus Castelnau, 1840 & 1 & 0 & 0 & 0 & 2 & 0 & 3 \\
\hline & Eurysternus sp. & 9 & 1 & 12 & 6 & 8 & 14 & 50 \\
\hline \multirow[t]{2}{*}{ Phanaeini } & Coprophanaeus saphirinus (Sturm, 1826) & 3 & 1 & 1 & 0 & 0 & 0 & 5 \\
\hline & Phanaeus splendidulus (Fabricius, 1781) & 1 & 0 & 3 & 0 & 0 & 0 & 4 \\
\hline Onthophagini & Onthophagus sp. & 0 & 0 & 4 & 0 & 8 & 1 & 13 \\
\hline \multirow[t]{13}{*}{ Canthonini } & Canthon latipes Blanchard, 1845 & 25 & 1 & 5 & 19 & 9 & 5 & 64 \\
\hline & Canthon rutilans Castelnau, 1840 & 0 & 0 & 0 & 0 & 3 & 0 & 3 \\
\hline & Canthon sp. & 4 & 0 & 0 & 4 & 0 & 0 & 8 \\
\hline & Canthonella sp. & 12 & 34 & 6 & 30 & 50 & 29 & 161 \\
\hline & Deltochilum brasiliense (Castelnau, 1840) & 8 & 7 & 8 & 5 & 0 & 3 & 31 \\
\hline & Deltochilum furcatum (Castelnau, 1840) & 32 & 9 & 17 & 23 & 1 & 9 & 91 \\
\hline & Deltochilum morbillosum Burmeister, 1848 & 5 & 10 & 1 & 16 & 0 & 1 & 33 \\
\hline & Deltochilum rubripenne (Gory, 1831) & 11 & 1 & 18 & 11 & 3 & 16 & 60 \\
\hline & Paracanthon pereirai d'Andretta \& Martínez, 1957 & 4 & 1 & 1 & 0 & 1 & 8 & 15 \\
\hline & Scybalocanthon nigriceps (Harold, 1868) & 12 & 0 & 18 & 107 & 14 & 52 & 203 \\
\hline & Sylvicanthon foveiventre (Schmidt, 1920) & 3 & 1 & 1 & 7 & 2 & 3 & 17 \\
\hline & Number of species & 26 & 23 & 30 & 24 & 25 & 22 & 39 \\
\hline & Number of individuals & 368 & 1380 & 672 & 514 & 285 & 305 & 3524 \\
\hline
\end{tabular}

When analyzing community structure based on individuals' abundance per species in each collection area and calculating between pairs of areas Morisita's similarity index, the cluster analysis showed that the valley and hillside areas are more similar among themselves than the secondary forest with eucalyptus and even more distinct from the hilltop (Figure 4).

The difference in composition of the community that inhabits the hilltop area becomes clear with the canonical correspondence analysis, where a habitat selection trend can be observed. Canthon rutilans Castelnau, 1840, Dichotomius carbonarius (Mannerheim, 1829), and Canthidium sp. 1 are species associated to places with smaller sized trees, and were only found at the hilltop. Onthophagus sp., Ateuchus near histrio (Balthasar, 1939), and Uroxys sp. 2 were found at the hilltop and at the southward hillside associated with smallsized, wide-crowned trees (Figure 5).

\section{DISCUSSION}

The overall community characteristics of Serra do Japi's dung beetles are not different from what would be expected from a tropical forest insect community structure. Many individuals and species were found as the result of climatic conditions that favor the development of these insects, which are predominantly tropical (Halffter \& Matthews 1966; Halftter \& Edmonds 1982; Hanski 1991; Gill 1991). 
The number of individuals and species collected during the year shows a trend towards seasonality, with smaller numbers during winter. Although several years of studies are needed to describe a seasonal pattern, it was possible to observe that many species are present throughout the year; there was not a clear division between summer and winter species in this sub-tropical community, as in other communities with similar climatic conditions (Hanski \& Cambefort 1991).

Serra do Japi's winter community is a sub-sample of the summer species, with the addition of only one species, Dichotomius bechynei (although with a very low abundance). It is possible that this species survives in vegetation remnants that maintain the humid soil; this fact was also observed in other locations, in areas of Atlantic Forest in the states of Rio de Janeiro, Minas Gerais, and São Paulo (FZVM, unpublished data). The presence of active species during winter that belong to genera Onthophagus, Eurysternus, and Uroxys seems to follow the same distribution pattern, although these are species that occur throughout the year. Studying winter communities' microgeographic, microclimatic, and age distribution could define whether these are survivors from summer communities or are bivoltine or multivoltine species. Such studies could also verify whether these communities are segregated into microregions which have retained high levels of humidity in winter or whether their distribution is the same as in the summer.

The difference in dung beetles abundance found between the areas showed an exaggerated abundance of a small-sized species, like Canthidium trinodosum (5.4 $\mathrm{mm}$ long), in the degraded valley when compared to the other areas. This is a common pattern among such insects, as these species are strongly influenced by the type of vegetation they inhabit and thus modify their pattern in degraded areas (Halffter et al. 1992; Davis et al. 2001; Halffter \& Arellano 2002). Another factor that represented pattern change in community composition was the absence of Scybalocanthon nigriceps in the degraded valley. This species, which is $9.3 \mathrm{~mm}$ long, is diurnal and is found between October and May (Hernández 2002), and could be used as an indicator species in the future.

The data collected on the insect fauna of several Atlantic forest areas could subsidize discussions on Serra do Japi's conservation, as these insects can help evaluate and monitor the area's state of conservation (Halffter et al. 1992; Halffter \& Favila 1993).

Acknowledgements. We thank Dr. Sérgio Furtado dos Reis, who advised the first author's doctorate thesis; CNPq, for granting scholarships; the Secretaria Municipal de Educação de Jundiaí-SP, for allowing the study at Serra do Japi; and to the people who work at the Base Ecológica da Serra. We also thank David Edmonds, Bruce Gill, and Gonzalo Halffter for reading the manuscript and contributing with valuable comments.

\section{REFERENCES}

Brown, K. S. Jr. \& G. G. Brown. 1992. Habitat alteration and species loss in Brazilian forest. In: Tropical deforestation and species extinction (eds. T. C. Whitmore \& J. A. Sayer). p. 119-142. Chapman and Hall, London.

Cambefort, Y. 1991. From Saprophagy to Coprophagy. In: Dung Beetle Ecology (eds. I. Hanski \& Y. Cambefort). pp. 22-35. Princeton University Press, Princeton. 481 p.

Davis, A. J.; J. D. Holloway; H. Huijbregts; J. Krikken; A. H. KirkSpriggs \& S. L. Sutton. 2001. Dung beetles as indicators of change in the forests of northern Borneo. Journal of Applied Ecology 38: $593-616$.

Davis, A. L. V. 1994. Habitat fragmentation in southern Africa and distributional response patterns in five specialist or generalist dung beetle families (Coleoptera). African Journal of Ecology 32: 192-207.

Didham, R. K.; P. M. Hammond; J. H. Lawton; P. Eggleton \& N. E. Stork. 1998. Beetle species responses to tropical forest fragmentation. Ecological Monographs, 68: 295-323.

Endres, A. A.; M. I. M. Hernández \& A. J. Creao-Duarte. 2005. Considerações sobre Coprophanaeus ensifer (Germar, 1824) (Coleoptera: Scarabaeidae) em um remanescente de Mata Atlântica no Estado da Paraíba, Brasil. Revista Brasileira de Entomologia 49: 427-429.

Endres, A. A.; A. J. Creão-Duarte \& M. I. M. Hernández. 2007. Diversidade de Scarabaeidae s. str. (Coleoptera) da Reserva Biológica Guaribas, Mamanguape, Paraíba, Brasil: uma comparação entre Mata Atlântica e Tabuleiro Nordestino. Revista Brasileira de Entomologia 51: 67-71.

Gardner, T. A.; M. I. M. Hernández; J. Barlow \& C. A. Peres. 2008. Understanding the biodiversity consequences of habitat change: the value of secondary and plantation forests for neotropical dung beetles. Journal of Applied Ecology 45: 883-893.

Gill, B. D. 1991. Dung Beetles in Tropical American Forests. In: Dung Beetle Ecology (eds. I. Hanski \& Y. Cambefort). pp. 211-229. Princeton University Press, Princeton. 481 p.

Halffter, G. \& E. G. Matthews. 1966. The natural history of dung beetles of the subfamily Scarabaeinae (Coleoptera, Scarabaeidae). Folia Entomológica Mexicana 12/14: 1-312.

Halffter, G. \& W. D. Edmonds. 1982. The Nesting Behavior of Dung Beetles (Scarabaeinae): An Ecological and Evolutive Approach. Instituto de Ecología, México, D. F., 176 p.

Halffter, G. \& M. E. Favila. 1993. The Scarabaeinae (Insecta: Coleoptera) an animal group for analysing, inventorying and monitoring biodiversity in tropical rain forest and modified landscapes. Biology International 27: 15-21.

Halffter, G. \& L. Arellano. 2002. Response of dung beetle diversity to human-induced changes in a tropical landscape. Biotropica 34: $144-154$.

Halffter, G.; M. E. Favila \& V. Halffter. 1992. A comparative study of the structure of the scarab guild in mexican tropical rain forest and derived ecosystems. Folia Entomológica Mexicana 84: 131156.

Hanski, I. 1991. The Dung Insect Comunity. In: Dung Beetle Ecology (eds. I. Hanski \& Y. Cambefort). pp. 5-21. Princeton University Press, Princeton. 481 p.

Hanski, I. \& Y. Cambefort. 1991. Resource Partitioning. In: Dung Beetle Ecology (eds. I. Hanski \& Y. Cambefort). pp. 330-349. Princeton University Press, Princeton. 481 p.

Hernández, M. I. M. 2002. The night and day of dung beetles (Coleoptera, Scarabaeidae) in the Serra do Japi, Brazil: elytra colour related to daily activity. Revista Brasileira de Entomologia 46: $597-600$

Hernández, M. I. M. 2003. Riqueza de Besouros Escarabeídeos em duas áreas de Floresta Atlântica no Estado da Paraíba. In: Congresso de Ecologia do Brasil - 6. Fortaleza, CE. Anais de Trabalhos Completos, Simpósio Floresta Pluvial Tropical Atlântica, Sociedade de Ecologia do Brasil. p. 300-302.

Howden, H. F. \& V. G. Nealis. 1975. Effects of clearing in a tropical rain forest on the composition of coprophagous scarab beetle fauna (Coleoptera). Biotropica 7: 77-83.

Janzen, D. H. 1983. Seasonal change in abundance of large nocturnal dung beetles (Scarabaeidae) in Costa Rican deciduous forest and 
adjacent horse pasture. Oikos 41: 274-283.

Kenney, A. J. \& C. J. Krebs. 2000. Programs for Ecological Methodology, $2^{\text {nd }}$ ed. University of British Columbia. Vancouver.

Klein, B. C. 1989. Effects of forest fragmentation on dung and carrion beetle communities in Central Amazonia. Ecology 70: 1715-1725.

Leitão-Filho, H. F. 1992. A flora arbórea da Serra do Japi. In: História Natural da Serra do Japi: Ecologia e Preservação de uma Área Florestal no Sudeste do Brasil (Org. L.P.C. Morellato). p. 40-62. Editora da UNICAMP/ FAPESP, Campinas. 321 p.

Lobo, J. M. \& F. Martín-Piera. 1999. Between-group differences in the Iberian dung beetle species-area relationship (Coleoptera: Scarabaeidae). Acta Oecologica 20: 587-597.

Louzada, J. N. C. \& F. S. Lopes. 1997. A comunidade de Scarabaeidae copro-necrófagos (Coleoptera) de um fragmento de Mata Atlântica. Revista Brasileira de Entomologia 41: 117-121.

McGeoch, M. A; B. J. V. Rensburg \& A. Botes. 2002. The verification and application of bioindicators: a case study of dung beetles in a savanna ecosystem. Journal of Applied Ecology 39: 661-672.

Ministério do Meio Ambiente. 1999. Diretrizes para a política de conservação e desenvolvimento sustentável da Mata Atlântica. Caderno n ${ }^{\circ} 13$. Brasília, DF, Brasil.
Peck, S. B. \& A. Forsyth. 1982. Composition, structure and competitive behaviour in a guild of Ecuadorian rain forest dung beetles (Coleoptera: Scarabaeidae). Canadian Journal of Zoology 60: 1624-1634.

Pinto, H. S. 1992. Clima da Serra do Japi. p. 30-38. In: História Natural da Serra do Japi: Ecologia e Preservação de uma Área Florestal no Sudeste do Brasil (Org. L. P. C. Morellato). Ed. UNICAMP/FAPESP, Campinas $321 \mathrm{p}$.

Statsoft, Inc. 1998. Statistica for Windows. Tulsa, OK.

Ter Braak, C. J. F. \& P. Smilauer. 1997-2002. Canoco for Windows, version 4.5. Biometris - Plant Research International, Wageningen, The Netherlands.

Vaz-de-Mello, F. Z. 2000. Estado atual de conhecimento dos Scarabaeidae s. str. (Coleoptera: Scarabaeoidea) do Brasil. p. 183195. In: Hacia un Proyecto CYTED para el Inventario y Estimación de la Diversidad Entomológica en Iberoamérica: PrIBES-2000. Martín-Piera, F., J. J. Morrone \& A. Melic (Eds.) vol.1, SEA, Zaragoza, 326 p.

Vaz-de-Mello, F. Z. \& J. N. C. Louzada. 1997. Considerações sobre o forrageio arbóreo por Scarabaeidae (Coleoptera,Scarabaeoidea), e dados sobre sua ocorrência em floresta tropical do Brasil. Acta Zoológica Mexicana 72: 55-61. 